\title{
Marco Frascari $\mid$ Architectural Traces of an Admirable Cipher: Eleven in the Opus of Carlo Scarpa
}

Consciously or unconsciously, part of the apparatus that architects use in their daily fabrications of the built environment grows out of their understanding of numbers and numerals. Marco Frascari examines the use of number and especially the number 11 in the architecture of Carlo Scarpa. In Scarpa's opus, it is true that One and One Equals Two, but it is also wonderfully true that $A$ Pair of Ones Makes an Eleven.

Imagination is everything (Raymond Roussel 1975, p. 279).

\section{Introduction}

In their daily fabrications of the built environment, architects deal with the various chiastic relationships between visible and invisible. Part of the apparatus that they use, consciously or unconsciously, to imagine future constructions grows out of their understanding of numbers and numerals. To divine future buildings they rely on numeracy. ${ }^{2}$ Architectural numeracy consists in neither objective nor subjective constructs based on an arithmetical use of numbers, but rather in sedimentations of experience, formed by matter and memory. By the agency of tectonic aspects controlled by numbers, architects relate visible construction with invisible constructs. By linking recollection and anticipations, architectural numeracy deals with the meanings of constructional aspects and gives new visual angles. By using poli-dimensional tools of transversal epistemologies such as "angelic numbers" and "monstrous numerals", the architect's control of numbers transacts tangible matter with intangible dreams. Numbers summon up in detailed examinations what is passing and what is to come. Embodied in tectonic events and parts, numbers hinge the past and the future of buildings and their inhabitants into a search for a way of life with no impairment caused by psychic activity. In due course, whether sensible or intelligible, tectonic numbers articulate the vigor of human mind's eye, and ultimately they refer to psychic regimes immersed in the vital ocean of imagination and wonder.

\section{Angelic numbers}

A thoughtful professor of number theory, Richard Friedberg (1968) points out that numbers have very specific characters. For instance, he sees the number three as "lumpy and dark", five as "pale and round like a ball". In addition, he affirms that numbers do not have colors, but have light. For him, all the numbers within the twenties seem flooded with light, whereas the 
numbers within the seventies are dark and mysterious (Friedberg 1968:11-12). The contrast between the theory of numbers and arithmetic is similar to the difference existing between poetry and grammar, this mathematician suggests. What distinguishes number theory is that its choice of material is governed by curiosity and wonder, whereas that of arithmetic is governed by use and convenience. (Friedberg 1968:21) However, this is not the present view held by the professors and the professionals of architecture in their daily handling of numbers. ${ }^{3}$ In current architectural theory and practice, numbers are mostly considered unbiased arithmetical signs. They are digital representations, instrumental accounts, used for graphic and constructive likeness. Seen and understood as mere syntactical expressions, numbers determine arithmetical links among the parts and the elements of construction or between drawings and buildings. They do not carry semantic value in themselves, and if meanings are achieved this is done only through metaphorical allusions. A number is considered meaningless unless it is actually related to units of dimensions, by which it becomes a digital measure, or evocatively related to building elements by which it becomes a metaphorical gauge. These are projective mappings by which building blocks, Graces, modules, Seasons, Trinities, Tetramorphes, units or other numerically referential components or details -such as 365 windows in a princely palace to denote a year- can be betokened in figures ruling the composition of tectonic elements within the built environment. Tradition, nowadays mostly alien to us, endowed the use of numbers in architecture with allegorical, iconic, mystical and symbolic meanings. In his treatise for building patrons, Leon Battista Alberti indicates that to achieve congruency or harmony in any architectural project it is necessary to deal with three active factors: numeratio (numbering), finitio (dimensioning), collocatio (setting). Numeratio is the proper selection of an elegant process of design numeracy to be used in building to achieve concinnitas (harmony). For instance, Alberti indicates that a good number is 40 , because "a patient recovers at the end of forty days." In this case, as in many other numerical selections, the exegesis of Alberti's text reveals the crucial anthropomorphic origin of numbers. ${ }^{4}$ This is a discrete chiasm between the parts of the body that are counted and the parts of the body that are named, a rhetorical procedure using body parts as tectonic locatives and vocatives (foot as measure and footing as foundation). Based on isomorphism, these processes of signification relate conventionally the number of the tectonic elements to other anthropomorphically iconic usages of numbers. Twelve columns might symbolize the 12 apostles, the 12 zodiac signs, or the 12 months. These numerical presences in architectural artifacts, besides dealing with instrumental aspects, build cosmological resonance. Negligible traces of these numerological traditions are present in the current practice and theorization of architecture. Many apothegms in the architectural discourse confirm the semiotic magnitude of numbers in architectural design and they are the tips of an iceberg that should have a major impact on design procedures. Recently revived by formalistic trends, one of these apothegms uses the power of number three: "a perfect facade or building has three parts, a base, a middle and a top." Another apothegm, devised by Carlo Scarpa (1906-1978) whose architectural opus will play an essential role in this discourse on the architectural efficacy of number, states that "paired columns are better than single ones." These apothegms are semiotically comparable to Pythagorean acusmata, philosophically prescribing statements. These design precepts, based on tectonic metonymies, set interaction between pragmatic frameworks and semantic dimensions through syntactic prescriptions. In other

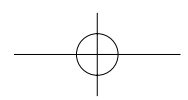


words, numbers, properly considered, become bearers of meaning in a wonderfully ${ }^{5}$ rich but discrete architecture. This is an architecture of substitution, where numerical hypotheses are replaced by a tectonic play of building elements related to numerical hypostasis. This is a relationship of conclusion dealing with higher and wider-ranging ideas and ciphering a material totality: an architectural opus. A continuous projection of signs, an opus is a true architectural project. An architectonic opus is not based on a specific building, but results from an uninterrupted act of design based on a continual search for the human measure both in past and in future constructed worlds. An act of architectural divination, this continuous projection of built signs, an infinite semiosis, is carried out, through a phenomenological cast of numerical embodiments and human measures. ${ }^{6}$ Tectonic meanings stem metonymically from numbers present in the built and human bodies. This process uses corporeal tropes as keys to images, which are crucial for figuring out the chiastic nature of architecture. Just as we think architecture with our bodies, we think our bodies through architecture. The rhetoric of this latter sentence displays a monstrous and curious chiasm, a hiatus, i.e. a mutual ascription of ciphers and figures between the human and architectural bodies. This bodily hiatus has been evident in the realm of the constructed world since builders used both their own bodies and the bodies of their sacrificial victims for inscribing their constructions with inferential meanings. The representation of architecture in bodies and of bodies in architecture began when the organization of built bodies loomed poetically on the labyrinthine quality of the numerals of the human body. This tradition suggested canons for the determination of measures and proportions and for the imagery to be used during the design and construction of buildings. The traditional interpretation of numbers in architecture distinguishes three main streams in the generation of meaning using the numerical lore, namely: the cosmological, the biblical and the magical numbers (Butler 1970:XI). The first stream originates within the Greek tradition and it is set up on a geometrical manipulation of numbers. The aim was to generate a cosmological understanding of the music of the spheres. The second stream springs from the tradition of biblical exegeses. The scope was to search for a harmonic structure of verbal intonations within a paramount text and its reflection in our world. The third stream arose within the magical body of knowledge presenting the abstract understanding of numbers as essences of the occult relationships existing between microcosm and macrocosm by setting the tradition of isopsephia or gematria (Butler 1970:1-46; Opsopaus 1995). Architectural theorists and practitioners unified these three currents by encrypting and deciphering numbers within a comprehensive view of the reality of things. Numbers became the form of forms, exemplary ciphers of all numerable things, visible and invisible, mortal and immortal, corporeal and ethereal. Numbers evolved as angular angels who then became the messengers of a Semiotica Harmonia generated by the construing and constructing of human, cosmological and theological aspects. Architecture was considered the most powerful manifestation of this tripartite congruity of ends, which was considered a reciprocal mirror between macrocosm and microcosm. Nevertheless, these traditional interpretations hold back architectural numerology to a very limited understanding of numeracy. If they are revived in their historic forms, the metaphoric nature of the numbers will dominate more than metonymic nature of numbers embodied within the tectonic extent and presence. The atectonic system of design regulating the contemporary realm of architecture will encourage metaphors as architectural essence of 
numbers; the results will be limited by historicism recoveries and fashionable formulas. Within this scenario, numbers are not mere instrumental presences, but they became trivial manifestations in the process of signification.

A superior scenario is the metonymic approach to numbers. A metonymy enlarges and enriches the semiosis of numbers in architectural design. Metonymy is critical for setting an unfaltering tectonic dependency from numbers. Within this aspect, numbers become one of the most important tools used by architects, builders, and inhabitants during the daily construction and construing of architectural artifacts. This presence of numbers in building elements and detailing facilitates the process of setting a relationship between the denotation and connotation in any architectural space. Metonymically speaking, paired columns become spatial hinges indicating entry on a façade or in a square, or structural markers for generating a direction in a built space. In tectonic numeracy, numbers must be considered identical with things since, following the suggestion of Nicholas of Cusa (1989:75), they are both space- and time-bound. In this sense, this new metonymic approach to architectural manipulation of numbers is very close to the Pythagorean figuring out of numbers (Brukert 1962:31) or to Wittgenstein's explanation of the common language manipulation of digits. The resulting architectural numeracy is then a "weak thinking" based on auctoritas or the authority of the architect's understanding of numbers. This auctoritas is achieved by the implementation of numerical demonstrations in construction. It is a Pythagorean procedure. Pythagoreanism has been, for the adepts of the occult sciences, a vast source of formulas calculated to intimidate and reduce to silence sensible judgment. However, in constructing the universe with theorems, devoid of controlled scientific observations, the Pythagoreans attribute to numbers and figures special qualities, but they also localized these diverse qualities, types, causes and substances in visible things, in different parts of the concrete reality. Their powerful tool kit was based on demonstrations: division, combination, appropriate moment (kairos), and proportions, the whole arsenal of numerical postulates set their authority. Numbers demonstrate the ultimate reason for things by revealing the specific imprints. Following this edifying direction, architectonic numeracy creates places and marks the tissues of concrete reality.

\section{Monstrous numbers}

The theory of architecture is established through demonstrations, and Carlo Scarpa's authoritative use of the number and numeral eleven is such a demonstration. In a discussion of the use of architectural numeracy, as I already mentioned, Scarpa's opus is fundamental for understanding the importance of number in architectural design since, in his handling of architectural metonymies, he presents a possible path for reconstructing a tectonic tradition of numeracy. An investigation of Scarpa's obsession with the number eleven, an extraordinarily odd number, can help to move away from the metaphors of Nuptial arithmetic and Pythagorean palaces to reach the metonymies of the Brunian logic of coincidences and phantasms, that is, mental representations of a real objects.

Eleven is both an intriguing numeral and a charming number that can help to demonstrate the numeracy unfolded by human constructions and construings. In China, eleven is the number of the Tao, but it is not taken in the quantitative sense of ten plus one since it signifies

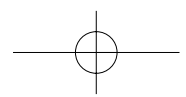


the unity of the decade in its wholeness (Franz, 1974:65 \& 147). Eleven appears as a factor, and a multiple, though not by itself, in the Imperial system of measuring: 5-1/2 yards equal one road, pole or perch; 4 perches equal 22 yards (a chain); 220 yards a furlong; 1750 [11x160] yards equal a mile (Wells, 1986:82). Eleven is the fifth number in the Lucas sequence:

$$
1 \ldots 3 \ldots 4 \ldots 7 \ldots 11 \ldots 18 \ldots 29 \ldots
$$

(Wells, 1986:83). Within the tradition of numerology, eleven is generally considered a number loaded with a negative sense. Eleven is wicked and evil. In the tragedy "The Piccolomini", Friedrich von Schiller states: "Eleven is the sin, eleven goes beyond the Ten Commandments". Eleven in medieval numerology is always interpreted as ad malem partem. A sixteen-century numerologist, Petrus Bungus asserts that eleven has no correlation with the divine. The Muslin Brethren of Purity considers eleven as the first mute number in the sequence of mute prime numbers after ten (Schimmel 1993). Dante bases the measures of the Inferno on eleven: in the tenth valley (bolgia) of the eighth circle of Hell, one of the damned tells Dante and Virgil that the circumference of the abyss is eleven miles (Inferno:XXX.87); during the visit of the ninth bolgia, Virgil tells Dante that the circumference is twenty-two miles (Inferno: XXIX.9).? However, a positive view of the transgressional power of eleven is in the number of the visible signs of the Zodiac, since one of the signs is always behind the sun, hence invisible. This is connoted in the story of Joseph's dream (Gen. 37:9) where the sun, the moon and eleven constellations render homage to him (Schimmel 1993: 190). Recently eleven has been interpreted as union between five $(2+3)$ and six $(2 \times 3)$ a hierogamos between macrocosm and microcosm. Another positive view of eleven, within the Christian tradition, is in the legend of St. Ursula. According to this sacred lore, St. Ursula traveled to Cologne in a fleet of eleven sailboats each of which carried 1000 virgins. It is striking to note that Scarpa designed the museum room housing Capriccio's canvases (teleri) of the story of St. Ursula at the Gallerie dell'Accademia, in Venice.

In architecture, the presence of eleven is exceptionally meager, but its peculiar properties of being a mute but transgressive number allow a profound perusal of the use of numerical affinities. The use of eleven is a departure from tradition, but it is also a compliance with tradition. In one of the few public lectures Scarpa has ever delivered, he states:

I need a certain kind of light and I worked everything on a grid of 5.5 centimeters. This motif seems nothing special, but it is actually rich in expressive scope and movement ... I measured every thing with the number 11 and 5.5. Since every thing was based on multiplication, everything fits and the measurement turns out right. Someone will object that the measurement will end up right even on a grid of 1 centimeter - but it's not true because 50 multiplied by 2 is 100, while 55 by 2 is 110, and if you ad another 55 it makes 165, not 150, and if you double that you get 220 and then 330, 440. In this way, you can divide up the parts and you'll never have 150 but 154. (Scarpa 1986) 
The understanding of the peculiarity bearing on the usage of eleven in Scarpa's numeratio must begin with the consideration of two Byzantine metonymies. On one hand, there is the bizarre fact that eleven letters composes the name and the family name of the Venetian architect, C-a-r-l-o S-c-a-r-p-a. ${ }^{8}$ On the other hand, there is the curious actuality that within Italian traditional construction techniques, the thickness of a standard hollow-tile partition wall is always just about $11 \mathrm{~cm}$, even if the nominal dimension is $10 \mathrm{~cm}(9 \mathrm{~cm}$ for the tile and $1 / 2$ $\mathrm{cm}$ of plaster on both sides). Outside of the nominalism of design specification, within the reality of construction, wall tiles are never assembled following a perfect plum-line and this reoccurring mistake is corrected by the mason by increasing the thickness of the plaster, thus bringing the total thickness of the partition wall to a real dimension of eleven centimeters. ${ }^{9}$ Both two dimensional events of substitution control Scarpa's transcendental numeracy.

Carlo Scarpa's interest in numbers is well established, not only through his statements, but also from his design drawings, which are rich of numerical annotations. This is in contrast to customary procedures, which see displays of numbers only in sensible construction drawings. Many are the numbers on Scarpa's drawings, but rather than arithmetical calculations they are combinatorial figures; the few calculations presented on the drawings are mostly arithmetically wrong. The essential influence on Scarpa's numerical thinking is the combinatorial procedures devised by Raymond Roussel for writing his books, the upturned geometry of Rene A. Schwaller De Lubicz and Surrealistic processes of invention. It was a family friend and professor of the University Ca' Foscari, Aldo Camerino, who introduced Scarpa to these methods of invention..$^{10}$ A Venetian Jew, Camerino hid in Scarpa's house during the last period of World War II. During the long hours of Camerino's forced reclusion within the walls of Scarpa's apartment in Venice, Scarpa received his education in cultural criticism and in the means of imagination developed and researched by the Surrealists and the French esoteric writers of 19th century. ${ }^{11}$ Another source for his peculiar numeracy is the sister of Scarpa's wife, Bice Lazzari. A musician and a weaver who also worked in architectural offices, Lazzari was one of the leading Italian abstract painters. She was also associated with the abstract reckonings of the artists working for the Galleria al Milione and the conceptual calculation of Carlo Belli's Kn (1938).

\section{Venice}

A stroll in Venice is probably the best way to understand the presence of number in architecture. Venice is an urban jigsaw puzzle that can lead us to the discovery of the truth of astounding architecture. Walking from the church of San Barnaba -where a magnificent Corinthian order is celebrated by the interlocking of three rows of columns on the corners of a beautifully proportioned NeoPalladian façade- to the church of the Angelo Raffaele -a magnificent baroque elevation with rigorous numerical expressions set on the mystical numbers of a Byzantine plan- there is a small campo $^{12}$, a spot where it is possible to see how a significant metamorphosis of the constructed environment took place. This campiello, a clearing in the forest of dwelling of Venice, is a place that can open our eyes to the opacity of dwelling. In this privileged Venetian locus solus, light and dark meet in the shades and shadows of edifices to generate an interpretation of the human expression of reality in the facts of 
construction. This is one of those places where the poetic dimension of dwelling can be measured auspiciously, an opus of architecture where a new understanding of architectural numeracy and combinatorics can be assimilated. The direct path between the two churches leads down Calle Lunga San Barnaba, which, as its name states, is among the longest Venetian calli. Just before we reach the beautiful, monumental apses of the church of the Angelo Raffaele, a small bridge ends the Calle by bringing us into a little campo, a campiello. The urbanity of the campiello is controlled spatially by the small façade of the church of San Sebastiano. Built circa 1540, the façade was designed by Antonio Abbondi, better known under the professional nickname of Scarpagnino. ${ }^{13}$ The façade is a playful metamorphosis of the traditional front elevation of Venetian churches. It illustrates an interesting attempt to introduce new building elements that did not belong to traditional ecclesiastic designs into the composition of a church front. Many of the elements used by Scarpagnino in the church façade are derivative of the secular tradition of Venetian palace façades. ${ }^{14}$ The out-of-theordinary feature is the occurrence of paired columns put on a single projecting pedestal at the edges of the façade. Paired columns had been used in other Venetian constructions such as San Zaccaria and Palazzo Vendramin-Calergi, but in San Sebastiano, the effect seems eccentric. The upper-story columns are shorter than the one below, and to make the two stories the same height, the upper columns were raised on pedestals. The reason for this peculiarity is that the columns predated the design and were utilized because they were available architectural spoils..$^{15}$ The result of this assembly is a puzzling and disjointed alignment with the other elements composing the façade setting a tectonic configuration, a result of architectural combinatorics. Scarpagnino, as many of the Venetian builders of that period, was erecting architectural configurations. Scarpa with his constructive detailing is also following the same design procedure of architectural configuration. A configuration is achieved every time that finite number of objects are assembled, and by respecting certain $a$ priori restrictions; Latin squares and finite geometries are recognized as configurations. However, the disposition of parcels of various dimension in a much too small container, or the disposition of words or idioms given a priori are also configurations, on condition that the fixed restrictions are sufficiently cunning.

Combinatorics and combinatorial geometry study configurations setting a dialectic between the visible and the hidden by way of a clean division between two terms that are supposed generally correlated, since the transparency of objects and events is paradoxically opposed to their legibility. Since Raymond Lull had artfully given us stair and wheels, combinatorics is an instrument for understanding the world; they demonstrate the existence of configurations of an intentional type and, if this existence turns out indubitable, they evenly or oddly enumerate by listing, or by optimization. Located on the south side of Campiello San Sebastiano, Scarpa's combinatory piece is the new entry to the group of buildings composing the monastery attached the church. Laid with a perspectival angle, which recalls that of the Imago Urbis of the Ideal Cities, the facade of the entryway is a thaumaturgic piece of architecture. It is the last "autograph piece" designed by Scarpa. The transformation of the monastery was completed in 1979, exactly one year after Scarpa's death. This entry, a critical piece of design, is an base of orsera (a white Istrian stone) within which is located the entry portal for few departments of the University of Venice, relocated within 
the monastery complex. This tactful assembly of stone pieces contains in its construction the discrete poetry of the number eleven.

Scarpa created his architectural poetry by metonymically using found fragments, architectural spoils of the constructed world. His tectonic poetry was brought into being by the growth of a tradition within the trade of modernity. The metonymical relationship between the part and the whole dominates Scarpa's architecture and many critics have labeled his architecture as fragmentary. However, the result is not a discrete architecture of mere instrumental or metaphorical representations; rather, tectonic staging and elemental signification are unified in the glorification of the virtual and real joints of a construction. In Scarpa's buildings, the power of tectonic imagination is the core of the architectural métier. ${ }^{16}$

Resting against the old facade of the Monastery of San Sebastiano, Scarpa's stone base is engaged in a productive dialogue with the facade of Scarpagnino. Thesis and counter-thesis are developed, and the argument is resolved in the joint between the two facades, where the lowest of the binary columns set by Scarpagnino engages the base designed by Scarpa. The two windows on the ground floor of the monastery have been closed by the slabs of orsera raised by Scarpa against the base of the facade. The original stone lintels showing above the stone base mark the memory of these window openings. In Scarpa's design, round ventilation holes replace the windows, ten round holes replacing the window near the door; sixteen the other. The graphic arrangement of these holes recalls the ancient Greek notational figure for odd numbers, but their configurations are different. What seem to us triangular (odd) numbers are instead square (even) numbers. The triangular composition of the orifices generates an even sum in every opening but one, which, of course, is the exception confirming the rule. This simple numerical artifice is a sign that architecture is a project based on a projective tectonic set among diverse construction elements, not a composition of similar parts.

Speculating on the amazing nature of numbers, Cusanus' Layman stated:

Number, in fact, is composed out of itself, since every number is acomposite of an even and an odd number. Thus number is composed out of number. If you said the number three is composed of three units, you would be speaking the way someone claims that walls and roof make a house when they still exist separately. For if the walls and the roof are separate, no house is composed from them. (Nicholas of Cusa 1989:72).

Scarpa's architecture is a prudent and playful project that relates to the traces of numbers embodied in a tradition. In this specific case, the tradition is the Venetian constructive ability to reconcile discrete building elements of disparate origin without becoming eclectic. Scarpagnino began the San Sebastiano project when he harmonized pilfered columns with his design of the facade; it was carried on by Scarpa's attuning numbers and numerals of ventilation openings. Scarpa's round holes also belong to a tradition, one which finds its most beautiful expression in the dozen of the ventilation holes used in the small passage connecting the church on the island of San Michele -designed by Mauro Codussi, a twelve-with the later addition of the Emiliana chapel. ${ }^{17}$ 
In his design of the entry facade, Scarpa is also introducing new elements resulting from the transmutation of fertile motifs that he had already developed in other designs. Here, the transmuted motif is a ziggurat-molding, which becomes the solution for the detailing of the entry door. Scarpa has used this architectural motif in several other occasions: in cast concrete form for a cemetery in the countryside and in red marble for a bank in a dense urban environment. Now the same motif in orsera is utilized for the entry to an institution of higher learning, in a quiet recess of a historical city. In the latter specific use of the fertile motif, the tectonic numeracy reveals that architecture is a corporeal project, not a typological composition. The corporeal image imposed on the artifacts by the means of numbers is a significant mask. This image becomes clear in the detail of the step leading to the door, a stone tongue gently protruding from the facade. The number used in the ziggurat is a multiple of eleven; the measure of each step is $5.5 \mathrm{~cm}$. Returning to Venice to find other uses of eleven as a powerful invention of inspired tectonic. We can find eleven in one of its best expression in another ecclesiastic building built a few years before S. Sebastiano. This is the church of Santa Maria dei Miracoli, designed by Pietro Lombardo. This church has 11 bays in the main body, and its nave is divided by a change of level marked by 11 steps. Outside, on the upper story of the facade, two oculi (round windows) mark the round-top pediment. The outside perimeter of these two round openings is decorated by 11 patens of precious marble, a decoration born from the Venetian tradition of slicing pilfered marble columns. Under these two windows there is a vertical dark mark, a stain caused by draining rainwater. This weathermark becomes a beauty mark in Scarpa's solution for the round windows in the Banca Popolare in Verona. In the plaster under the round opening, Scarpa has inserted a vertical molding $5.5 \mathrm{~cm}$ wide. A pair of vertical filets composing the molding controls the dark rain mark by transforming it in dark shadows. An ugly effect becomes a discreet decoration born under the sign of wonder. These round Scarpian windows lead us to another dimension of architectural numeracy. The greatest architectural wonder is in the use of proportions and again Nicholas of Cusa's Layman teaches us:

Without number, it is not possible for proportion to exist. Proportion is the realm of forms, for without a proportion suitable and adapted to a form, the form is not able to appear. As I have said, the form of the spoon is not able to remain once the proportion suitable to it is ruined. It would not have a location. Its proportion is like the aptitude of the surface of the mirror for the reflection of an image. Once this fails, the representation ceases to exist. Observe the way in which the infinite unity of an exemplar is able to appear only in a suitable proportion. Number is such a proportion. (Nicholas of Cusa 1989:72-73).

The proportional geometry of the circles of the windows of the bank in Verona is extremely peculiar. They are what Scarpa used to call "dynamic circles". They are built by using a circle with a radius of five dimensional units intersected with another circle with the same diameter with the distance between the two centers of one unit. The interior half circles are erased and two segments equal to one unit then connect the two remaining half circles. The result of this construction is a dynamic circle that, in one direction, has a diameter of eleven units; for example, if the diameter 
of the initial circle is $100 \mathrm{~cm}$, the dynamic diameter is $110 \mathrm{~cm}$. The dimensional unit used in the Verona's windows is Scarpa's canonical $5.5 \mathrm{~cm}$. Scarpa used the same proportional geometry in designing the molding with the two filets and this set of canonical set of hendeca-measures and the same two filets -of course in a different scale- are used in the design of the spoon, fork and knife that Scarpa designed for silversmith Cleto Munari on November 6, 1977.

Scarpa's interlocking circles are based on a similar procedure of dynamic and proportional geometry. Two circles are traced and the main distance between exterior half circled is of eleven units and the centers of the two circles are respectively on the marks of the third and eighth unit. Scarpa, as a good Venetian architect, derived his decorative profiles and figures from the sectioning of columns. Scarpa's decorative interlocking circles are thus derived from a metaphorical section of Palladio's interlocking columns on the front porch of Palazzo Chiericatti in Vicenza, a place where Scarpa used to play marbles as a child, as he stated on an interview broadcast by the Italian television. Scarpa derived his interlocking circles from the section of the two interlocking columns in the colonnade marking the passage from the main line of the front porch to the protruding central part of it.

The most famous instance of Scarpa's interlocking circles is in the entry Pavilion of the Brion Cemetery, in San Vito d'Altivole. Many critics acknowledge this graveyard as Scarpa's masterpiece, and the architect himself selected it as his own burial ground. After moving past the natural curtain of weeping willow, which masks the entrance of the Brion Mausoleum, the visitor does not face the dim and gloomy interior of a burial chamber, but a short corridor facing a window made with two interlocking rings opening onto a lawn. Situated within a wall of cast-inplace concrete, this opening is framed by two rings made with a circularly bent I profile of steel. A decoration of pink and light blue tesserae of Venetian glass mosaic is embedded within the canals of the profile section. One ring is pink and the other is blue. On the other side of the wall, the colors are reversed. In these two circles, fundamental canonical proportions such as root-two or the Golden Mean are ignored. Instead, a proportion of duplicity is present, duplicity touched but never fully reached; to be precise, the duplicity of eleven.

Scarpa's funeral was the first to be held in the chapel he designed for the Brions. Scarpa is buried in a piece of ground in a fold of the wall enclosing the Brion graveyard. The grave is ambiguously located between the private and the public sections of the cemetery. A flat-lying tombstone designed by his son Tobia marks Scarpa's burial place. The dominant decoration is a grid of small black dots marked on Scarpa's favorite dimension of $5.5 \mathrm{~cm}$. The Greek word sema, which means tomb and grave in one of its many usages, does not merely refer to a place of interment, but implicitly refers to it as marked place, as one where a corpse has been ritually interred. Adolf Loos (1985) clearly indicates that the beginning of architecture is in the mound erected to mark the grave of a peasant in the middle of a wood, not in the overornate symbolic palace in the city. The semantic use of numbers has the same ritual beginning, a tectonic presence. Various human activities necessary to the wonder of construction lead to the use of numerals in human activities such as counting, measuring, shaping, forming, estimating, moving, celebrating, calculating, proving, puzzling and so on. A calendar is the result of relating many of those activities to a cosmological changing of seasons. The Roman calendar was of eleven months. As the Latin origin of the name states, December was the tenth month and January was the eleventh month, which marked the

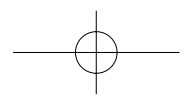


ending and the beginning of the year. February did not count; it was a period in between, a period when people suffered of fevers (Februa=Februaris). The first month of the year was March (Sabbaducci 1988:9-12,38-40). January was the month devoted to Janus, the Roman god of beginnings and endings. Embodied by human imagination in powerful architectural elements, Janus is the god of doors, gates, arches, and bridges. He has two faces: one looking toward the future and the other toward the past. Thinking of these peculiar divine qualities of Janus we can trace the tectonic qualities of eleven in the ambiguity between its nature of being a cardinal number between 10 and 12 and its character of being the smallest repunit, a number whose digits are all units. In other words, Janus is a perfect mythical representation of the peculiar event that in architecture it is true that Eleven equals One + One. Scarpa secularized this mythical event in the wonderful incidents of his architectural opus, on the one hand an assimilation of Venetian construction and construing and on the other hand an elaboration of a tectonic philosophy, conceived as perplexity where the constructional thought is seen as conjecture, and architectural poetry as the deepest form of rationality. This is derived from a line of the manifesto proclaiming immaginismo:

The life seen through the biconvex lens of the immaginismo, only warranty for the eternity, can be reassumed in the formulas: $2=1 ; 1=2 ; 1+1=1 .{ }^{18}$

In Scarpa's opus the duality of the architectural element and detailing is a constant theme: railings have always double supports, the elegant bridge of the Fondazione Querini Stampalia has two parallel hand-railings. The acme of this effect of duality is the most beautiful architectural hinge ever designed by Scarpa: the placement of the statue of Cangrande Della Scala in the Museum of Castelvecchio in Verona. This spatial joint it is an amplification of the most knotty and problematic cut up of the building, a tie done by void in a figurative and spatial implication. In this theatre of the memory of the layers of two different constructions that must live together, the art of detailing makes the verisimilar agree with the admirable (mirabile). In this sense, the dual detailing becomes more than a composition of parts, it becomes a project. One plus one is then a combinatorial method for generating non-trivial architectural inventions, by which the architectural numeracy becomes the material cause of poiesis, generating 'architectural possibilities or potentialities'. Above this knotty space of the museum of Castelvecchio, the ridge beam, which by constructional definition is a singularity, is actually transformed in a duality. Two beams hold the top of the roof. On them rest the top chords of the timber truss holding the main roof which had been metamorphosed in king posts made by a piece of timber in compression and two iron rods put in tension on twin struts.

For Scarpa, eleven is a marchingegno, a contrivance and clever expedient. ${ }^{19} \mathrm{It}$ is a powerful surrealist machine, as the eleven wheels and double-counterweight pulley of the glass door located in the entry pavilion of the Brion Cemetery. This marchingegno is an eleven machine marking the entry to a special place, an island in the middle of a pool that Scarpa called Locus Solus in memory of Roussel's masterpiece. This marchingegno is a "bachelor machine", as are the machines elaborated by Roussel for his Parisian Locus Solus. To open, the metal and glass panel of this liminal machine must be pushed down in a slot cut in the floor. Under the floor, there is a trench as large as the passage, which connects with the big pool of water. When this 
amazing door is closed by pulling the glass and metal panel back up, it drips water and watergrasses all over its shining surfaces. Placed on the outside of the concrete wall enclosing the narrow passage, the humorously intriguing double counterweight assures the effortlessness of the vertical movement. The balance of this counterweight is controlled by a constellation of pulley wheels, which make tremendous and discordant sounds every time the rope connected to the inside door begins to move. Glass doors are the negation of wonder since you can see what is beyond it, but in this instance, Scarpa has elaborated a macchina admirabilis. There is a double effect: not only does the image beyond the glass panel become blurred when the door is pulled up to close the passage, but at the same time the machine casts a terrifying sound of the cranking of eleven rusty wheels, an architectural approach to the mysterious reality of Michel Carrouges's Machines célibataires.

\title{
Conclusion
}

In Scarpa's opus, it is true that One and One Equals Two, but it is also wonderfully true that A Pair of Ones Makes an Eleven. These secular combinatorial events are statements of architectural numeracy, a discipline of conjectural and experiential explanations and divinations which recognizes regional and anthropomorphic tectonics as the footing for the use of numbers in the architectural project, and following Nicholas of Cusa's lead we can assert:

\begin{abstract}
Number is the exemplar of our mind's concept. Without number, the mind cannot do anything. Neither assimilation, conception, discretion, nor measurement would occur if number did not exist. In the absence of number, things cannot be understood as separate and discrete. Nor without number, is one thing understood to be substance, another quality, and so on for the other categories. Consequently nothing can be understood without numbers, because it is the mode of understanding. (Nicholas of Cusa 1989:74)
\end{abstract}

By relying on numeracy in their constructional alchemy, architects deal the relationships between the detectable and the undetectable of present, past and future structures. Their numerical plays of assimilation, conception, discretion and building measures, elements and details are neither objective nor subjective constructs but alchemic distillation of bits and pieces of materials, dream stuff and memory. By means of tectonic numbers, architects relate visible edifices with invisible edification. Numbers summon up in iconic examinations of what is passing and what is to come by transacting tangible matter with intangible materials by relating recollection and anticipations. Tectonic numbers hinge the forgotten and the imminent of buildings. In due course, whether sensible or intelligible, these numbers articulate the drive of human imagination and ultimately they refer to intuitive regimes of human life engrossed into them. When buildings are interwoven with the pathos of number, they are machines that sensually, sexually, intellectually and emotionally arouse human beings, who react to them, relate with them, and never show apathy to them. 


\section{Notes}

1. An earlier unfocused and shorter version of this paper was published in the magazine $O Z, 13$, (1991), with the title "Deciphering of a Wonderful Cipher: Eleven in the architecture of Carlo Scarpa." This rewriting of the article dealing with Scarpa's utilization of number and numeral 11 as measure and imaginary device results from the remark made about my article by Kenneth Frampton in a footnote of his book on tectonics (Frampton n.23, p. 408, 1995). The changes from the original version are fairly significant, enough to make it necessary to treat the present version as a distinct text for purposes of correct reference.

2. For an anthropological view of numeracy, see Crump 1998; for its invisible presence see also Noss 1997.

3. In proposing a search for an architecture that produces thauma (Greek: wonder) and therefore being thaumaturgic, my aim is to suggest an approach to the study of the theories of architecture from a humorously elegant and playful point of view. In their drawings, architects announce what will come to be. This architectural foretelling is an act of visualization; an understanding based on interpretative procedures, a serious play, which analyzes writings, drawings and buildings under an awe-inspiring humor. Wonder stimulates a person to probe. It intensifies when the inquiry succeeds and the enigmatic becomes intelligible in a vivid image of conception. In architecture, this topical thinking is a constructive curiosity that observes tectonic events and marvels at them. Architectural theory, then, concerns itself with demonstrative knowledge.

4. Alberti is following one of the most traditional lines of numeracy, as Rene Thom (1974:77) points out, "number as sign grows out of living things".

5. In the Classical Greek world, admiration was a way for generating questions, whereas nowadays wonder is only stuporous contemplation without proper divination. The way to solve this impasse is to take a third way, a way looming to angels; not those of the official theology, but those of Rilke, Cacciari and Coteau. Discretion is a synthetic activity of the intellect. Proceeding from the knowledge of what architecture is, discretion sets out the means by which the works of wonderful architecture are brought into being. The exercise of discretion is thus a synthetic activity reversing the Cartesian analytical procedure of abstraction. Discrete architecture is a union of theory and practice, a construction of the discrete parts resulting from the application of imagination. This is the vis imaginativa accomplished within the reality of the art of building. This vis imaginativa is based on form of philosophical thoughts labeled "weak thinking". Weak thinking is a procedure, neither aggressive nor domineering. Grounded in a convalescent ontology, weak thinking is rather gentle and tangential (Vattimo 1984, 1988, 1990). This is a convincing practice for centering admiration rather than developing precise scientific eccentricity. Weak thinking is a militant but discrete philosophy, translated into the realm of architecture on the pages of some Italian architectural magazines. Casabella, Lotus and Ottagono were the magazines involved in the debate (De Sola Morales 1989, Gregotti 1989, and Vattimo 1988). Weak thinking, a process of discrete thinking, will lead us to a future of wonderfully discreet architecture avoiding popular metaphors reducing poetic thinking merely to a wondrous tautology without any critical power.

6. Semiosis is the process by which meanings are attached to signs; the triad of symbols, indexes, and icons is a powerful configuration that can be used to classify signs. An index is a sign related by contiguity, e.g., smoke is an indexical sign of fire. An icon is a sign related by similarity, e.g., a portrait is an iconic sign of the portrayed person. A symbol is a sign related by convention, e.g., a gilded column in the loggia of the Ducal Palace of Venice marks the arch where the Doge used to appear to deliver his speeches to the Venetian people.

7. For a discussion of the sinful nature of eleven and Dante's application of the number and measured reconstructions of the Inferno, see Kirkham (1989).

8. I am a 13. Anton Francesco Doni was an 18, Antonio Abbondi, called the Scarpagnino, was a 14 but nicknamed 11. Italo Calvino is a 12, but he wrote an architectural treatise discussing fifty-five cities of eleven different types arranged in nine groups identified with Roman numerals. Roman numeral are mirroring devices: $\mathrm{X}$ for 10 is two mirroring $\mathrm{V}$ for 5; C for 100 is two mirroring $\mathrm{L}$ for 50 .

9. Scarpa, in his drawing, requested that partition walls had to be drafted with the real measure of $11 \mathrm{~cm}$ rather than the nominal $10 \mathrm{~cm}$.

10. Camerino as cultural figure is extremely complex.

11. The Proto-Surrealist Raymond Roussel is one of Scarpa's preferred writers. The Brion cemetery has been designed with many references to two of Roussel's novels, Locus Solus and Impressions of Africa. Located in real places, they are fictional creations of Roussel, cryptographic and combinatorial writing procedures. Roussel 
died in a room of The Hotel Delle Palme in Palermo which Scarpa would later request when there during the designing of the Abbatellis Palace. Aldo Camerino wrote a well known piece on Roussel in 1935, and he was also the translator of many of the surrealist texts, calligrams.

12. Calle is the Venetian word for the narrow streets between houses of the city. Campo is an open place. In Venice, there is only one piazza: Piazza San Marco, Saint Mark's Square.

13. In the Venetian language, scarpagnino is a diminutive form used to indicate a small chisel or stone carver, while scarpa is a normal chisel.

14. For instance, pedimented windows are found only in schools or palaces. The design attempt by Scarpagnino is similar to the one developed in the luminous design of the facade of San Michele in Isola, designed by Mauro Codussi.

15. Venetians built most of their city using building spoils coming from all their trading routes.

16. Although interested in the architecture of Aalto, Le Corbusier, Wright, Wagner, Loos and Hoffmann, Scarpa was above all interested in the stones of Venice. Scarpa's architecture is regional: the architectural traditions of Venice are the hidden representations. Every Scarpa building contains invisible parts of Venice. Scarpa did not design within an historical eclectic dimension. His designs were based on a continuous trade with history producing new building elements to be assimilated in the architecture of Venice. The facades of Scarpa and Scarpagnino are stones of Venice that speak of architecture as embodied knowledge. They demonstrate that architecture is a traditional knowledge, which allows translation of ideas from one field to another, and as a way of letting thoughts hang around.

17. Scarpa had use these ventilation holes also in the entry gate at the Fondazione Masieri.

18. The manifesto of the Immaginismo was published in 1927; cf. Tonini 1996. Paladini in 1931 wrote an article in Rassegna Italiana entitled "Del Razionalismo in Architettura". In 1931 Scarpa signed the letter that the Razionalisti Veneziani sent to Il Lavoro Fascista (Dal Co pp.279-280).

19. Marchingegno is a curious Italian word combining "to mark" with the word machine, meaning a mental or physical device that operates cunningly; cf. Frascari 1993.

\section{References}

OTL Aicher. Analogous and Digital. Berlin: Ernst \& Sohn, 1994.

LeOn Battista Alberti. Ten Books on Architecture. James Leoni, trans. 1726. Rpt. London: Tiranti, 1955.

Carlo Belli. Kn. Milan: Il Milione, 1935.

Claude Bragdon. The Beautiful Necessity: Seven Essays on Theosophy and Architecture. New York: Quest Books, 1978.

Walter Burkert. Lore and Science in Ancient Pythagoreanism. Cambridge, MA: Harvard University Press, 1972.

Christopher ButLer. Number Symbolism. New York, 1970.

Massimo CaCCIARI. The Necessary Angel. Albany: SUNY Press, 1994.

Aldo Camerino. Cari Fantasmi. Milan: Mondadori, 1966.

Michel Carrouges. Les Machines célibataires. Paris: Arcanes, 1953.

ERnest CASSIRER. Philosophy of Symbolic Forms. 3 vols. Yale: Yale University Press, 1953-1957.

C. Calvin Clawson. Mathematical Mysteries. The Beauty and Magic of Numbers. New York: Plenum Press, 1996.

Thomas CRump. The Anthropology of Numbers. Cambridge: Cambridge University Press, 1992.

IGNASI De SOla MORALES, "Weak architecture." Ottagono, 92.

UMberTO ECO. A Theory of Semiotics. Bloomington: Indiana University Press, 1976.

Kenneth Frampton. Studies in Tectonic Culture: The Poetics of Construction in Nineteenth and Twentieth Century Architecture. Cambridge, MA: MIT Press, 1995.

Marie-Louise VON Franz. Number and Time: Reflections Leading toward a Unification of Depth Psychology and Physics. Evanston, IL: Northwestern University Press, 1974.

Frascari, Marco, "The Compass and the Crafty Art of Architecture." Modulus 22 (1993), pp.3-27.

Richard Friedberg. An Adventurer's Guide to Number Theory. New York: McGraw-Hill, 1968.

Georges PereC and Harry MatheWs. "et Venise. Esquisse d'une géographie mélancolique.” L'Arc 68, (1977), pp. 9-25.

Vittorio Gregotti. "The Weakness of Criticism." Casabella 562 (1990), pp.2-3 and 63.

Giovanna Grossato. "Bice Lazzari, dall'Informale al Materico e ritorno." Nautilus Web Magazine, vol. 3, no. 1. GEORGES IfRAH. From One to Zero: a Universal History of Numbers. Harmondsworth, 1987.

AdOlf LoOs. "Architecture." The Architecture of Adolf Loos. London: Precision Press, 1985.

Andrea Martines. "La letteratura combinatoria." Doctorate thesis, Università degli Studi di Roma "Tor Vergata", 
Facoltà di Lettere e Filosofia, 1996/97.

KarL MenNinger. Number Words and Number Symbols : A Cultural History of Numbers, 1958 and 1969. Rpt. New York: Dover, 1992.

NichOlas OF CuSA. The Layman on Wisdom and the Mind. Ottawa: Dovehouse, 1989.

RicHARD Noss, "New Cultures, New Numeracies." Inaugural Professorial Lecture,

University of London, 7 Oct. 1997.

John Opsopaus. Some Notes on the History of Isopsephia (Gematria). Biblioteca Arcane, 1995.

DAN Pedoe. Geometry and the Visual Arts. New York: Dover, 1976.

Joseph Ransdall. "On Pierce's Conception of the Iconic Sign.” Iconicity. Tübingen: Stauffenbing-Verlag, 1986, pp.51-74.

R. RICORDA. "Aldo Camerino prosatore." Quaderno veneti, 1993, n. 17, pp. 167-195.

RaINer Maria RilKe. Duino Elegies. New York: Norton, 1978.

PaOlo Rossi. Clavis Universalis. Arti della memoria e logica combinatoria da Lullo a Leibniz. Bologna: Il Mulino, 1983.

RAYMOND Roussel. Locus Solus. 1914.

Raymond Roussel. Comment j'ai écrit certains de mes livres. Paris: J.J. Pauvert, 1963.

DARIO SABBADUCCI. La Religione di Roma Antica dal calendario festivo all'ordine cosmico. Milan: Il Saggaiatore, 1988.

Carlo Scarpa. "Madrid Lecture." Carlo Scarpa. The Complete Works. F. Dal Co and G. Mazzariol, eds. New York, 1986.

AnNemarie Schimmel. The Mystery of Numbers. Oxford: Oxford University Press, 1994.

René SCHWAller de LubicZ. Simbolo e simbolica. Rome: Arkeios, 1997.

René SCHWAller De Lubicz. Etude sur les nombre. Paris: Librairie de l'art Indépendant, 1914.

René Schwaller de Lubicz. Le Temple dans l'Homme Apet du Sud a Luxor. 3 vols. 1957.

Thomas A. Sebeok. "Six Species of Signs." Semiotica, 13, 1975, pp. 233-260.

Michel Serres. Les Origines De La Geometrie. Paris: Flammarioun, 1993.

Eric Temple-Bell. The Magic of Numbers, 1946. Rpt. New York: Dover.

RENe ThOM. Modeles Mathematiques de la Morphogenese. Paris: UGE, 1974.

PaOlo TONInI, CURATOR. "Bolscevico Imaginista" by Vinicio Paladini. A virtual exhibit: http://www.tzm.it/sba/Mostre/Paladini/index.htm

Gianni Vattimo. "Ornament/Monument." The End of Modernity. Baltimore: The John Hopkins University Press, 1988, pp. 80-89.

Gianni Vattimo. "Dialectics, Difference and Weak Thought." Graduate Faculty Philosophy Journal, vol 10, n.1 (1984), pp. 151-165.

Gianni Vattimo. "The End of Modernity. The End of the Project." Journal of Philosophy and the Visual Arts, 1990, pp.74-77.

Vitruvius. On Architecture. Books I-X. Frank Granger, trans. 2 vols. 1931. Loeb Classical Library. Rpt. Cambridge, MA: Harvard University Press, 1998.

DAVID WelLS. The Penguin Dictionary of Curious and Interesting Numbers. New York: Penguin USA, 1992.

LuDWIG Wittgenstein. Philosophical Investigations. 3rd. ed. New York: Prentice-Hall, 1973.

Ludwig Wittgenstein. Wittgenstein's Lectures on the Foundation of Mathematics. Harvestener Press, 1939.

Rudolf WitTKOWER. Architectural Principles in the Age of Humanism. London: 1962.

CRISPIN WRIGHT. Wittgenstein on the Foundation of Mathematics. Cambridge, MA:Harvard University Press, 1980.

\section{About the author.}

Marco Frascari graduated in Architecture in 1969 in Venice, and since then has been practicing architecture on a small scale and writing about it. He completed his studies at the University of Pennsylvania with a Ph.D. in Architecture in 1983. He is G.Truman Ward Professor of Architecture at WAAC Virginia Tech. In addition, he has taught at the University of Pennsylvania, Columbia, Harvard, Georgia Tech, IUAV and the Architectural Association. He has published several articles, a book entitled The Monsters of Architecture (Rowman \& Littlefield, 1991), and lately a very tiny book entitled Una Pillola per sognare... l'architettura (Editrice Progetti, 1995). He is presently working on an enlarged English version entitled The Dream House of Architecture. Recently he has been appointed by the Bishop as architectural consultant for the restoration of Alberti's Sant' Andrea in Mantua. His current interest is in the elegant nature of tectonic imagination. 